\title{
Queer minulost' pripomínaná v prvorepublikovej tlači československej sexuálnej menšiny
}

\section{Queer past commemorated in press of the sexual minority during the first Czechoslovak Republic}

\author{
Michal Mako / mizuumako@gmail.com \\ Historický ústav, Filozofická fakulta, Masarykova univerzita
}

\begin{abstract}
History is an endless well of diverse stories and events from which individuals, small groups of the population, minorities, majorities, nations or humanity itself choose what is important to their image of not only historical reality.

Queer history often transcends the notion of narrowly understood boundaries of nations, religions, social classes, gender, or other social categories. In this paper I would like to answer the question - what historical events or personalities were most often commemorated by the Czechoslovak queer community in the First Czechoslovak Republic (1918-1938) and why? The answer to this main question will be aided by an analysis of the press of the Czechoslovak sexual minority from the period of the First Czechoslovak Republic.
\end{abstract}

\section{Keywords}

homosexuality, the First Czechoslovak Republic, queer history, commemoration, collective memory 


\section{1 Úvod}

Minulost’ je nekonečnou studnicou rozmanitých príbehov a udalostí, z ktorých si jednotlivec, malé skupiny obyvatel'stva, minority, majority, národy či ludstvo samé, vyberajú to, čo je dôležité pre ich utváranie obrazu o nielen historickej realite. Každá l'udská spoločnost’ si utvára istú podobu svojej subjektívnej historickej skutočnosti, a je celkom pochopitel'né, že sa utieka práve k takej minulosti, ktorá ju podla jej mienky čo najvýstižnejšie reprezentuje. Dôvodov, prečo je tomu tak, bude zrejme viacero. Tento fenomén pomenoval celkom trefne Marcus Garvey (1887-1940), jamajský novinár a podnikatel, ktorý vyslovil myšlienku, že „Lud bez znalosti svojej histórie, pôvodu a kultúry, je ako strom bez koreña “. ${ }^{1}$ Proces pripomínania si minulosti teda často súvisí s hladaním podstaty prežívanej reality, s hl’adaním odpovedí na otázky súvisiace so súčasnými problémami, a to prostredníctvom osvetlenia ich príčin a vývoja. Okrem toho slúži rovnako k legitimizácii a stabilizácii spoločenských, politických, kultúrnych či iných štruktúr.

Queer dejiny často prekračujú pomyselné úzko chápané hranice národov, náboženstiev, spoločenských vrstiev, genderu či iných sociálnych kategórií. Je preto podla mňa zaujímavé nahliadnut do toho, čo si pripomínala komunita l’udí, ktorá sa vymykala tradičnej spoločenskej stratifikácii a nastolenému poriadku. Reč je o „sexuálnej“ alebo aj „queer“ minorite. Teda o takej spoločenskej skupine obyvatel’stva, ktorej základnou spoločnou charakteristickou črtou je nekonformné sexuálne správanie a prejavy vymykajúce sa tradičnému väčšinovému heterosexuálnemu a binárnemu genderovému systému. ${ }^{2}$

To, v čom sa táto skupina obyvatel'stva však nepochybne nelíši od „klasickej, tradičnej“ väčšinovej spoločnosti, je spôsob, akým pracuje s inštrumentalizáciou svojej minulosti. Utváraná kolektívna pamät tu rovnako slúži ako spoločenská funkcia a aktualizácia historického vedomia. Údaje, ktoré sprostredkúva, majú zámernú aktualizačnú či inštrumentalizačnú úlohu. ${ }^{3}$

Ciel’om príspevku je otestovanie tejto hypotézy na príklade pripomínania si queer minulosti v období Československej republiky (1918-1938). K tomu poslúži obsahová analýza prvorepublikovej tlače československej sexuálnej menšiny a typizácia nadobudnutých informácií. Dôležité tak budú otázky: koho a čo si pripomína československá sexuálna

1 V origináli „A people without the knowledge of their history, origin and culture is like a tree without roots. "Marcus Garvey citáty / citaty.net, https:/ / citaty.net/autori/marcus-garvey/, citováno 12. 3. 2020.

2 Na všetkých miestach nasledujúceho textu teda používam pojem queer v takomto kontexte a význame. K problematike pojmu queer, queer štúdií či queer teórie pozri napr.: Ciprová, Kristýna: Queer v Česku. In: Himl, Pavel - Seidl, Jan - Schindler, Franz (edd.): Miluji tvory svého pohlaví. Homosexualita v dějinách a společnosti českých zemí. Praha 2013, s. 597-612.; Kobová, Lubica: Queer a podrývanie identity: queer teória a feminizmus. In: Kiczková, Zuzana - Szapuová, Mariana: Rodové štúdiá. Súčasné diskusie, problémy a perspektívy. Bratislava 2011, s. 312-331.; Demčišák, Ján: Kategória queer a jej analytický potenciál. Trnava 2015, 76 s.; alebo tiež „učebnicu“ queer štúdií Jagose, Annamarie: Queer Theory: An Introduction. New York 1996, $153 \mathrm{~s}$.

3 Problematiku historickej, kolektívnej či kultúrnej pamäte bližšie rozoberajú napr. významné práce: Halbwachs, Maurice: The Collective Memory. New York 1980, 186 s.; Assmann, Jan: Cultural Memory and Early Civilization: Writing, Remembrance, and Political Imagination. Cambridge 2011, 319 s.; Nora, Pierre: Rethinking France: Les Lieux de mémoire (volume 1-4). Chicago 1999-2010. 
menšina v prvorepublikovej tlači a prečo? Kto je tvorcom, objednávatel’om a udržiavatelom tejto kolektívnej pamäte?

\section{Prvorepubliková tlač československej sexuálnej menšiny v širších historických súvislostiach}

Od čias, kedy sa sexuálna morálka spoločnosti v Európe stala doménou krestanských cirkví, sa homosexuálne aktivity začali výraznejšie a širšie postihovat. Krestanská náuka mala potrebu organizovat mravný život obyvatelov, v dôsledku čoho postupne vznikalo cirkevné právo, ktoré sa snažilo o jasné vymedzenie hraníc l'udského morálneho konania. Jeho súčastou sa stalo definovanie etických noriem v oblasti sexuálneho života človeka. Zmysel pohlavného zblíženia l'udí tkvel výlučne v reprodukcii. Odmietaná bola erotická rozkoš či zmyselnost'. Každý pohlavný styk, ktorého účelom nebolo rozširovanie potomstva sa považoval za „sodomiu“.4 V 13. storočí prijala väčšina Európy legislatívu, ktorá zaviedla hrdelné tresty za homosexuálne aktivity. ${ }^{5}$ Stáročia trvajúce stredoveké trestné postihovanie homosexuálnych stykov sa stalo dedičstvom moderných európskych národných štátov, nevynímajúc Československú republiku (1918-1938). ${ }^{6}$

Až do konca 18. storočia boli ludské sexuálne praktiky predmetom kanonického práva, krestanskej pastorácie a svetských zákonníkov. Každý jeden z nich vytváral rámec dovoleného či nedovoleného. Sex zákonných partnerov bol pretkaný pravidlami a odporúčaniami. Najintenzívnejším ohniskom donucovaných príkazov sa stal manželský vztah. ${ }^{7}$ So vznikom modernej sexuológie sa však otvorila „Pandorina skrinka“. Enormná pozornost’ sa začala venovat’ tým, ktorí vybočovali zo zaužívaných stredovekých sexuálnych pravidiel spoločnosti. V priebehu jediného storočia boli títo l'udia stigmatizovaní ako „morálne šialeni“, nositelia „genitálnej neurózy“, „aberácie prokreačného zmyslu“, „degenerácie“ či „duševnej nevyváženosti“. 8

Historik, sociológ a filozof Michel Foucault (1926-1984) považuje toto historické obdobie za počiatok vzniku a vývoja tzv. modernej homosexuálnej identity. A to najmä z dôvodu, že hon na periférne sexuality so sebou prinášal tvorbu nových špecifikácií. Niekdajšia stredoveká sodomia, ktorá bola iba typom zakázaného činu občianskeho či kanonického práva, sa v 19. storočí transformuje na špecifickú osobnostnú, prirodzenú

4 Najčastejšie išlo o smilstvo človeka so zvieratom, smilstvo s osobou rovnakého pohlavia či o masturbáciu.

5 Spencer, Colin: Dejiny homosexuality. Bratislava 1999, s. 75-80.

6 Československá republika recipovala po svojom vzniku v roku 1918 rakúsko-uhorský právny poriadok. Na území Slovenska a Podkarpatskej Rusi platil nad’alej pôvodný uhorský trestný zákonník z roku 1878, ktorý mužskú homosexualitu postihoval ako „smilstvo proti prírode“ v \$ 241 a 242 uh. tr.z. Na území Čiech, Sliezska a Moravy platil nad’alej pôvodný rakúsky trestný zákonník z roku 1852, ktorý postihoval mužskú ale aj ženskú homosexualitu ako „smilstvo proti přírodě“ v § 129 b, rak. tr.z. Uhorský trestný zákonnik o zločinoch a prečinoch. 1878.; Rakúsky trestný zákonnik o zločinoch, prečinoch a priestupkoch. 1852.

7 Foucault, Michel: Dějiny sexuality I. Vưle k věděni. Praha 1999, s. 46-48.

8 Tamže, s. 49-50. 
vlastnost’ a charakter konkrétneho človeka. Kým stredoveký sodomita bol „iba“ heretikom, moderný homosexuál ${ }^{9}$ je už reprezentantom l’udského druhu. ${ }^{10}$

Výsledok načrtnutého procesu vzniku a tvorby tzv. modernej homosexuálnej identity má svoju jasne viditel’nú podobu na súčasnom území Česka a Slovenska až po vzniku Československej republiky v roku 1918. Niet preň lepší dôkaz, než je samotná existencia kompaktného a koordinovaného hnutia československej sexuálnej menšiny, ktoré systematicky bojovalo za dekriminalizáciu homosexuálnych stykov, s čím sa spájal takisto ciel’avedomý boj za vlastné sebaurčenie, rovnost’ a l’udské práva v kontexte československej society. ${ }^{11}$

V období prvej ČSR je možné zaevidovat minimálne štyri základné platformy hnutia sexuálnej menšiny, na ktorých aktívne presadzovalo svoj boj. ${ }^{12}$ Zrejme najsilnejšou a najlepšie reflektujúcou platformou hnutia bola jeho prvorepubliková tlač. Tá spĺňala mnohé funkcie, od štandardnej informačnej a zábavnej, až po interpretačnú, socializačnú či agitačnú. Vo svojej interpretačnej a agitačnej funkcii sa snažila o vykladanie rôznorodých sociálnych súvislostí a o formovanie verejnej mienky. Stala sa preto významným nástrojom tvorby a ovplyvňovania spoločenských, ale aj politických postojov svojich čitatel'ov.

V socializačnej funkcii šlo o vysvetl'ovanie a komentovanie významov rôznorodých udalostí, aktuálne platných spoločenských vzţahov a informácií, o deklarovanie protiváhy najmä voči ustáleným štátnym právnickým autoritám a spoločensky zavedeným zvyklostiam v súvislosti s intoleranciou sexuálnej inakosti.

Táto tlač mala snahu združovat’ československých neheterosexuálnych občanov a v politickej rovine artikulovat ich záujmy, čím sa mala zvýšit jej relevancia. Nešlo totiž iba o záujmy niekol'kých izolovaných jednotlivcov. Deklaratívny program tlače československej sexuálnej menšiny sformuloval jej šéfredaktor František Černý (1886-1954) v štyroch základných bodoch. Vzhladom na sledovaný predmet môjho textu uvádzam ako najpodstatnejšie nasledujúce body : „1. Bojujeme za odstraněni pres sto let starého trestního zákona a hlavně jeho § 129 a o zrovnoprávněni homosexuálně založených osob s heterosexuálnimi, jak před zákonem, tak i před společnosti. 2. Pracujeme $k$ navázáni styku se všemi vědeckými, pokro-

9 S termínom homosexualita prichádza po prvýkrát mad’arský autor s nemeckými koreňmi Karl Maria Kertbeny (1824-1882) v pamflete z roku 1869 adresovanom královskému pruskému ministrovi spravodlivosti dr. Adolfovi Leonhardtovi (1815-1880). Pietruchová, Ol'ga: Homosexualita, spoločnost’ a politika. In: Triangel: homosexualita - spoločnost’ - politika. Bratislava 2007, s. 18. Človeka s erotickou prítažlivostou k rovnakému pohlaviu už skôr pomenovávali označenia ako napr. „urning“ alebo „invertovaný“.

10 Foucault, M.: Dějiny sexuality I., s. 53.

11 Pred vznikom Československej republiky sa objavilo iba niekolkko samostatných, na seba nenadväzujúcich verejných vystúpení proti kriminalizácii homosexuality. Príkladom je tzv. „podřipský anonym“ zaslaný v roku 1868 českému lekárovi a fyziológovi Janovi Evangelistovi Purkyněmu (1787-1869) alebo vystúpenie českého básnika, spisovatel’a a literárneho kritika Jiřího Karáska ze Lvovic (1871-1951) v časopise Moderni revue v roku 1895. Viac Seidl, Jan a kol.: Od žaláře $k$ oltáři. Emancipace homosexuality v českých zemích od roku 1867 do současnosti. Brno 2012, s. 65-69 a 79-87.

12 Okrem tlače sa hnutie formovalo na princípe zakladania a pôsobenia spolkov. Prvým zamýšlaným, no štátom nepovoleným spolkom bola pražská Vědecko-humanni společnost (1923) - neskôr s opätovným neúspešným pokusom o založenie pod názvom Společnost pro sexuálni bádáni (1925). Druhým, už úspešným počinom, bolo založenie spolku Československá liga pro sexuálni reformu (od 1932) a napokon tretím Osvětové a společenské sdruženi Přátelstvi (od 1932). Viac Tamže, s. 146-156 a 202-214. 
kovými korporacemi, se zákonodárnými institucemi za účelem odstraněni starých nespravedlivých předsudki̊. Tohto úkolu bude nám dožadovati se cestou zákonnou, přednáškami, tiskem atd. [...] 4. Spojit všechny homosexuálně a bisexuálně založené osoby v jednu pevnou nepolitickou organisaci, již účelem bude vedle humánniho, kulturniho, hospodářského a sociálního zájmu bojovati za práva a uznáni sexuálnich menšin. "13 $\mathrm{O}$ naplnenie tohto programu sa usilovali dva konkrétne časopisy: pražský Hlas a brniansky Kamarád.

\section{1 Časopisy Hlas a Kamarád}

Prvotným periodikom československého hnutia sexuálnej menšiny bol časopis, ktorého názov sa ustálil v základnej forme Hlas. Periodikum vychádzalo s rôznymi modifikáciami titulu $^{14}$ v rokoch 1931 až 1938 v Prahe. V apríli 1931 vyšlo jeho prvé číslo s označením Hlas sexuálni menšiny a podtitulom Zájmy uznávané vědou a kulturnimi státy. Prvým majitel’om a zodpovedným redaktorom sa stal kapitán československej armády vo výslužbe František Černý (1886-1954). Hlavným spolupracovníkom pri redigovaní a vydávaní časopisu bol spočiatku jeho brat Vojtěch Černý (1893-1938). V nasledujúcom priebehu činnosti časopisu sa vystriedalo niekol'ko d’alších majitelov, šéfredaktorov či členov redakcie. ${ }^{15}$ Periodikum obsahovalo emancipačné, beletristické a zábavné články s inzertnou rubrikou na konci. Hlas nebol výlučne politicky profilovanou tlačou. Mal ambíciu stat sa skôr spoločenskou revue queer subkultúry s politickým presahom. Z toho dôvodu bol zasielaný zdarma na niekol'ko mienkotvorných miest ako napr. do knižníc ministerstiev, poslaneckým klubom, významným činitel’om politického a kultúrneho života, policajným orgánom či sudcovským organizáciám a pod. V roku 1932 sa stal oficiálnym orgánom spolku Československá liga pro sexuálni reformu, d’alšej platformy hnutia. ${ }^{16}$

Druhou tlačovinou československej sexuálnej menšiny bol brniansky časopis Kamarád s podtitulom Časopis věnovaný zájmům prátelství uznaným vědou a kulturními státy. Pokus o periodické vydávanie d’alšieho queer magazínu priniesol na Moravu slovenský umelec Štefan Leonard Kostelníček (1900-1949) v roku 1932. Jeho hlavným cielom bolo podporenie a posilnenie programu pražského Hlasu. Po formálnej a obsahovej stránke išlo takmer o identické tlačoviny. Kamarád rovnako obsahoval emancipačné, politické, spolkovo organizačné, agitačné a beletristické články spolu so zoznamovacou rubrikou v závere. Vydané však bolo 28. mája 1932 v Brne iba jeho jediné číslo. ${ }^{17}$

13 Náš program. Hlas sexuální menšiny. Zájmy uznávané vědou a kulturními státy 1, 1. 6. 1931, č. 3, s. 1 .

14 Hlas sexuálni menšiny (1931), Hlas. List sexuálni menšiny (1932), Nový hlas (1932-1934), Hlas, list pro sexuální reformu (1936-1937), Hlas př́rody (1938).

15 V časopise figurovali osoby ako napr. podnikatel Antonín Steimar (1890-1944), nakladatel' Josef Hladký (1885-1960), právnik, režisér a dramaturg Vladimír Kolátor (1903-1986), právnik a advokát František Čeřovský (1881-1962), slovenský úradník Imrich Matyáš (1896-1974), úradníčka, žurnalistka a spisovatel'ka Jana Mattuschová (1906-2000) a d’alší.

16 Kvalitne spracované informácie aj o prvorepublikovej československej tlači sexuálnej menšiny ponúka: Lishaugen, Roar-Seidl, Jan: Generace Hlasu. Česká meziválečná homoerotická literatura a její tvưrci. In: Homosexualita v dějinách české kultury. Praha 2011, s. 209-280.

17 Seidl, J. a kol.: Od žaláře k oltáríi, s. 182-188. 


\section{Pripomínaná queer minulost'}

Záujem o minulosṫ ako o zdroj poznania či skôr inšpirácie pri konštruovaní vlastného pôvodu a identity sa objavuje už pred vznikom národných štátov v 19. storočí. Dôvodom bol tlak požiadavky na legitimáciu, reprezentáciu a sociálnu identitu v situácii súperenia mnohých ranonovovekých spoločenských a politických diferenciačných pohybov.

K budovaniu tzv. modernej homosexuálnej identity sa využívala tak, ako je to bežné u hocktorej inej sociálnej skupiny obyvatel'stva a tvorby jej identity, história a utváranie kolektívnej pamäte. Dochádzalo k tomu rozličnými spôsobmi inštitucionálnej, ale aj neinštitucionálnej povahy. V nasledujúcom texte som sa zameral najmä na oficiálnu formu snahy o konštituovanie kolektívnej pamäte československej queer menšiny, a to prostredníctvom periodickej tlače, ktorá mala práve na začiatku 20. storočia skutočne dôležitý sociálny, politický a kultúrny význam nielen v československom kontexte.

Ústredný moment pripomínania si minulosti v prvorepublikovej periodickej tlači československej sexuálnej menšiny úplne napíňal zmysel deklarovaného programu hnutia. Historické príspevky a články v časopisoch boli vyberané a písané takým spôsobom, aby čo najlepšie vystihovali naratív agitačnej akcie. Neustále sa v nich poukazovalo na kontinuálnost existencie homosexuality vo všetkých dejinných etapách ludstva, na jej celosvetovú spoločenskú ukotvenoste či prítomnoste. Týmto spôsobom sa hnutie usilovalo o legitimáciu inakosti, ktorú samo reprezentovalo. Inštalovalo sexuálnu menšinu ako sociálnu skupinu globálnej ludskej spoločnosti. Hnutie zdôrazňovalo, že sexuálna minorita tu „má svoje miesto, bola, je a bude tu vždy.“

Ďalším základným účelom historických článkov v predmetnej tlači bolo poukazovanie na prirodzenoste či „normálnoste", ludskost̉ a spoločenský prínos homosexuálneho človeka. Množstvo príspevkov približovalo útrapy, bolesti, krivdy, ale aj pozitívne životné udalosti, výnimočnosti či vel'ké spoločenské úspechy rôznorodých slávnych neheterosexuálnych ludí naprieč svetovými a československými dejinami. Zdôraznené bolo pričinenie sa týchto osobností o blaho celej väčšinovej spoločnosti, ich užitočnost̉ a ušlachtilost'.

Spomenuté prvky pripomínania si vlastných dejín mali evidentne slúžit k emancipácii queer osôb a k budovaniu ich kolektívnej pamäte. Toto budovanie prebiehalo v akýchsi dvoch základných rovinách, vnútornej a vonkajšej. Prostredníctvom prvej roviny hnutie využívalo minulosṫ k prehovoru „dovnútra“, k vlastnej komunite. Reprezentovali ju emancipačné, aktivizačné, osmelujúce snahy, ktoré vo svojej podstate odkazovali : „Verte si! Dôverujte si! Nehanbite sa za seba! Bud’te tým, kým ste! Pracujte! Zvelad’ujte! Aktivizujte sa! Pomáhajte si navzájom! Držte spolu! Žite ušlachtilo!... Tak, ako to robili vaši predkovia!“

Vonkajšiu rovinu zase charakterizuje príhovor hnutia k väčšinovej spoločnosti. Využitie minulosti v tejto druhej rovine opät predstavovali emancipačné, ale takisto aj politicky agitačné články, ktoré vo svojom jadre vyhlasovali : „Boli, sme a budeme tu! Sme normálni! Prestaňte nás trestat!! Prestaňte nás ponižovat a utláčat! Berte nás vážne! Nekrivdite nám! Nepodceňujte nás! Prijmite nás! Vieme a dokážeme toho vela!... Tak, ako naši predkovia!“

Pripomínanie queer minulosti a jej odkazov prebiehalo dvomi základnými formami. Prostredníctvom článkov a zdielaných informácií o rôznorodých osobnostiach dejín 
spätých akýmkolvek pozitívnym spôsobom s témou neheterosexuálnej inakosti, a takisto skrze dejinné, v niektorých prípadoch aj prítomné, spoločenské kultúry v rôznorodých geografických dížkach a šírkach. ${ }^{18} \mathrm{Na}$ nasledujúcich riadkoch prinášam analýzu konkrétnych príkladov.

\subsection{Pripomínané osobnosti}

Antropologické jadro kultúrnej pamäte predstavuje spomienka na zosnulých. ${ }^{19}$ Rodiaca sa moderná homosexuálna identita si žiadala uchovávat̉ a pripomínat pamiatku tých, ktorých životné svedectvá mali význam pre jej prítomnost'. Takisto je nutné poznamenat, že morálny záväzok k vybraným historickým osobnostiam často tkvie vo vyznaní určitej spoločensko-politickej identity. V predmetnej tlači je možné vyabstrahovat’ niekol'ko typov osobností, resp. vyzdvihovania ich podobných motívov, ktoré si hnutie opakovane pripomínalo najmä pri výročiach narodení, úmrtí alebo pri iných významných udalostiach či príležitostiach.

\subsubsection{Osobnosti hnutia sexuálnej menšiny - aktivisti}

Prvým typom sú osobnosti, ktoré si československé hnutie sexuálnej menšiny pripomínalo v tlači z toho dôvodu, že svojou aktivitou započali významný, aktívny a cielavedomý boj za l'udské práva a slobodu neheterosexuálnych l'udí. ${ }^{20}$ Pri článkoch o týchto osobnostiach je typickým prvkom naratívu vyjadrovanie obdivu, vyzdvihovanie pozitívnych ludských vlastností ako napr. genialita, múdrosṫ, ušlachtiloste, bojovnosť či pracovitost́. Často sa tiež spomínajú termíny humanizmus a aktivizmus. V niektorých prípadoch sa stretávame aj so skutočne silnými hyperbolami. ${ }^{21}$ Aktivistickým osobnostiam sa vyjadruje vernost', vd’aka, blahoželá sa im, uctieva sa ich pamiatka, označujú sa za vzor a nabáda sa k ich nasledovaniu.

Najčastejšie oslavované aktivistické osobnosti pochádzali z nemecky hovoriaceho prostredia, a to z dôvodu, že najvýraznejšie ovplyvňovalo samotné československé sexuálne hnutie. Symptomatickou osobnostou tohto rangu, najčastejšie pripomínanou, bol nemecký sexuológ a aktivista Magnus Hirschfeld (1868-1935). Zdôrazňovaná bola jeho neúnavná činnost̉ nielen pri zakladaní a udržiavaní Vedecko-humanitárneho výboru ${ }^{22}$

18 Detailnejšie o problematike pripomínania si queer minulosti, resp. o jej apologetickej funkcii, či tiež o konštruovaní „vlastných kultúrnych (queer) dejín“ pojednávajú: Putna, Martin C.: Homosexualita v novodobé české literatuře. In: Homosexualita v dějinách české kultury. Praha 2011, s. 83-183.; Lishaugen, RoarSeidl, Jan: Generace Hlasu. Česká meziválečná homoerotická literatura a její tvůrci. In: Tamže, s. 209-280.

19 Assmann, Aleida: Prostory vzpomínáni. Podoby a proměny kulturní paměti. Praha 2018, s. 35.

20 Najfrekventovanejšie boli snahy o všeobecnú dekriminalizáciu homosexuality.

21 Nemecký sexuológ a aktivista Magnus Hirschfeld (1868-1935) bol označený za „proroka, svätca, mudrca, filozofa“ či „najzaslúženejšieho bojovnika za rovnoprávnost homosexuálnych. “ 65 let Dr. M. Hirschfelda. Nový hlas 2, 1933, s. 72.

22 Orig. Wissenschaftlich-Humanitäre Komitee vznikla 15. mája 1897 v Berlíne. 
v Berlíne, prvej organizácie na svete, ktorá systematicky bojovala za práva neheterosexuálnych ludí. ${ }^{23}$ Tlač o Hirschfeldovi informovala kontinuálne počas celého svojho pôsobenia. Prvýkrát hned' v druhom čísle pražského Hlasu: „Je to on, ktorý nad všetkými pochybnostiami dokázal, že homosexualita je prirodzená vnútorná konštitucia, nezavinena nikým, ktorá nikomu na svete žiadne zlo nesposobuje a nie je to vobec chorobou a žiada preto úplne oslobodenie ich pred zákonom a l’udom. " ${ }^{24}$ Následne sa opät pripomínajú jeho zásluhy v roku 1932 nielen v Hlase ${ }^{25}$, ale aj v brnianskom Kamarádovi.$^{26}$ V roku 1933 sa objavuje d’alší článok pri príležitosti osláv 65. narodenín lekára. ${ }^{27}$ Posledný známy článok o Hirschfeldovi pochádza z roku 1936, kedy tlač upriamila pozornost̉ na jeho úmrtie. ${ }^{28}$

Za prvého právnického bojovníka za práva homosexuálov bol v analyzovanej tlači označený nemecký právnik a novinár Karl Heinrich Ulrichs (1825-1895), ktorý údajne dokázal nezmyselnost’ prenasledovania homosexuality ešte pred Hirschfeldom a obetoval svoj život boju za l’udské práva. ${ }^{29}$ Autor článku o Ulrichsovi, Imrich Matyáš (1896-1974) prináša okrem životopisu takisto kritiku homosexuálnej komunity, ktorá sa podla jeho názoru nedostatočne angažuje v zápase o vlastné l’udské práva. Rovnako tak vyjadruje lútost' nad ignoranciou uctievania pamiatky „vel'kého bojovníka“. Čitatel’ov preto vyzýva: „Každý homosexuálný a bisexuálný nech si berie priklad od svojho šlachetného Ulrichsa a nech nastúpi cestu v boji o vítazstvo svojej slobody. "30

Špecifické miesto v kontexte aktivistických osobností zaujal Jiří Karásek ze Lvovic (1871-1951), český básnik a spisovatel. Ten bol zase titulovaný ako „prvý bojovník“, priekopník boja za práva „invertovaných“31 osôb v Československu. Venované mu bolo takmer celé 15 . číslo Hlasu v roku $1931 .{ }^{32}$ Je však dôležité upozornit čitatela na fakt, že Karásek sa v tom čase stále aktívne podiel’al na vydávaní časopisu Hlas. Historický rozmer malo pripomínanie literárnych úspechov autora, ${ }^{33}$ jeho jedinečnosti a nenahraditel'nej práce pre československé hnutie sexuálnej menšiny.

23 Fanel, Jiř́i: Gay historie. Praha 2000, s. 7.

24 Zdravotný radca Dr. Magnus Hirschfeld. Od Imricha Matyáša z Bratislavy. Hlas sexuální menšiny 1, 15. 5. 1931, č. 2 , s. 4 .

25 Osvobozovacia akcia dr. Magnusa Hirschfelda. Piše Imrich Matyáš z Bratislavy. Nový hlas. List pro sexuální reformu 1, 1. 7. 1932, č. 3, s. 3-6.

26 Vzpomináme! Kamarád. Časopis věnovaný zájmům přátelství uznaným vědou a kulturními státy 1 , 28. 5. 1932, č. 1, s. 6.

2765 let Dr. M. Hirschfelda. Nový hlas 2, 1933, s. 72.

28 Spomienka na Dr. Magnusa Hirschfelda. Hlas, list pro sexuální reformu 3, 1. 10. 1936, č. 1, s. 4-5.

29 „Pre homosexuálných ludi si pracoval, pre nich si obetoval všetko, svoje meno, poziciu, peniaze a i to najvzácnejšie, svoju slobodu. "Karol Heinrich Ulrichs 1825-1895. Hlas sexuální menšiny 1, 17. 12. 1931, č. 16, s. 7.

30 Karol Heinrich Ulrichs 1825-1895. Hlas sexuální menšiny 1, 17. 12. 1931, č. 16, s. 8.

31 Pozri poznámku pod čiarou č. 9 na s. 4.

32 Pruý bojounik. Hlas sexuální menšiny 1, 1. 12. 1931, č. 15, s. 1-2.

33 „...v těchto veršich byla po prvé v naši literatuře zjevena pravda, s niž se veřejnost do té doby zabývala vždy jen $v$ soudnich sinich, kde ovšsm bylo to pak něco, čemu mnoho chybělo nejen do krásy, nýbrž i do prosté důstojnosti lidského duševního jevu." Tamže, s. 1. 
Okrem troch spomenutých príkladov osobností sa ich v tlači objavuje ešte niekol'ko. Ocenení sú napr. nemecký židovský esejista, právnik a novinár Kurt Hiller (1885-1972), ${ }^{34}$ protestantský teológ a farár Georg Plock (1865-1930), kníhkupec a vydavatel' Max Spohr (1850-1905), sexuológ Ernst Burchard (1876-1920) či advokát a prekladatel' Hermann Freiherr von Teschenberg (1866-1911).

\subsubsection{Osobnosti vedy}

Predstavitelia druhého typu pripomínaných osobností priamo nevystupovali v sexuálnom hnutí, no svojou prácou na vedeckom poli podla neho prispeli k spravodlivejšiemu posudzovaniu neheterosexuálnych osôb. Ich prelomové poznatky najmä z lekárskej vedy úplne zapadali do agitačného konceptu, a práve preto sa stali dôvodom nutnej pripomienky. Najčastejšie išlo o poukázanie na vrodenost̉ či prirodzenost’ homosexuality, ktorú teda nemá zmysel právne postihovat. Vedeckým autoritám, ktoré ponúkali takéto objasnenie genézy homosexuality bola vzdávaná vd’aka, prejavovaná úcta k ich pamiatke. Podla tlače tiež oplývali múdrostou, inteligenciou, vzdelanostou či spravodlivostou.

Za prvého lekárskeho bojovníka o rovnoprávnosṫ homosexuálov bol tak označený viedenský psychiater Richard von Krafft-Ebing (1840-1902), ktorý vo svojej knihe Psychopathia sexualis $^{35}$ načrtol nový smer k posudzovaniu pohlavného života človeka vo všeobecnosti a poukázal na krivdy páchané na homosexuáloch. ${ }^{36}$ Okrem Krafft-Ebinga sa tlač zmieňuje o švajčiarskom psychiatrovi Augustovi Forelovi (1848-1931) v samostatnom článku v súvislosti s jeho úmrtím. Pri príležitosti uctenia si pamiatky sa dostáva do popredia poukázanie na výsledky lekárovej práce, ktorá sa zaoberala otázkami psychopatológie: „Ano, prestalo tlouci dobré srdce velikého lidumila, učence a badatele, který dal světu největši poklad, pravdu! '37 Pravdou je v tomto kontexte označené nesprávne ponímanie pohlavnej otázky, o ktorom píše Forel vo svojom diele Die sexuelle Frage, ${ }^{38}$ a cez ktoré vyzýva k odstráneniu spoločenských predsudkov nielen voči homosexuálom.

V pozitívnom svetle je vykreslená práca aj d’alších osobností lekárskej vedy ako napr. talianskeho psychiatra a antropológa Cesara Lombrosa (1835-1909), anglického sexuológa a spisovatela Ellisa Havelocka (1859-1939), či nemeckých sexuológov a psychiatrov Iwana Blocha (1872-1922) a Alberta Molla (1891-1939).

34 K osobnosti Kurta Hillera vyšiel v Hlase samostatný článok: Dr. Kurt Hiller. Hlas sexuální menšiny 1, 31. 10. 1931, č. 13, s. 5-7.

35 Krafft-Ebing, Richard: Psychopathia Sexualis. Philadelphia 1894, 436 s.

36 „...neslýchaným gestom poukázal na krivdy, spáchané na l’ud’och, ktorí bez ich viny zo strany zákona a človečenstva pre ich sexuálne založenie sú prenasledovaní.. " Osvobozovacia akcia dr. Magnusa Hirschfelda. Píše Imrich Matyáš z Bratislavy. Nový hlas. List pro sexuální reformu 1, 1. 7. 1932, č. 3, s. 3.

37 Věčné památce profesora dr. Augusta Forela. Hlas sexuální menšiny 1, 14. 8. 1931, č. 7-8, s. 1.

38 Forel, Auguste: Die sexuelle Frage. Eine naturwissenschaftliche, psychologische, hygienische und soziologische Studie für Gebildete. Mníchov 1907, 658 s. 


\subsubsection{Osobnosti umenia}

Tretím typom pripomínaných sú osobnosti umenia, ktoré svojou jedinečnou umeleckou prácou dokázali podl’a predmetnej tlače obohatit’ celkovú väčšinovú „normálnu“ populáciu. Zároveň išlo o osoby, ktoré bud' priamo alebo nepriamo vykazovali neheterosexuálne znaky, teda svojím osobným a sexuálnym životom nepasovali do zaužívaného binárneho heterosexuálneho spoločenského štandardu. Pri tejto kategórii osobností predkladala tlač stručné životopisy, približovala životné útrapy, ale aj úspechy umelcov a umelkýň. Zdôrazňovala výnimočný talent, jedinečnost', šikovnost', prínos pre majoritnú societu a mnohokrát takisto poukazovala na ich spoločenskú obet: „Jejich vynikajici zásluhy, zejména vynikajici ušlechtilé vlastnosti a kvality jejich charakteru, jako lidi jsou nejlepši zárukou, že to nebyli lidé špatní, nebo prostopašníci, na jaké cejchuje lidi homosexualni náš trestni zákon. "अ9

Najčastejšie opakovane spomínanou osobnostou bol írsky básnik, prozaik a dramatik Oscar Wilde (1854-1900). V tlači neúnavne rezonovalo trestné stíhanie a právoplatné odsúdenie spisovatel'a z roku 1895 pre jeho homosexuálne styky. Pražský Hlas považoval túto udalost̉ za absolútnu tragédiu, ktorá Wildea zhodila na úplné duševné i materiálne dno. Po dvojročnom väzení v Readingu básnika prepustili na slobodu ako „bytost podlomenou, na těle i duchu zničenou, pouhý stín bývalého Wildea... "40 Akcentovanie neštastia poukazovalo na fakt, že paragraf trestajúci súkromný sexuálny život dostal slávneho dramatika z vrcholu kariéry a ohromného umeleckého prínosu pre celú spoločnost̉ do jej suterénu. Československé hnutie sexuálnej menšiny videlo vo Wildeovi v podstate obet nedávno uskutočnenej, stále živej justičnej vraždy: „Neznal jiné lásky než té, kterou mu příroda dala $a$ - té padl za obět. " "41

Hnutie na umelca spomínalo s pietou prostredníctvom tlače, v ktorej mu venovalo básne, ${ }^{42}$ emotívnu reč k pamiatke jeho života a diela, ${ }^{43}$ uverejnilo niekol'ko úryvkov jeho novely De Profundis (1897) na pokračovanie ${ }^{44}$ či dramaturgickú úpravu románu The Picture of Dorian Gray (1891). ${ }^{45}$ Okrem toho pri príležitosti 75 . výročia narodenia umelca

39 Autor článku uverejneného v Hlase František Čeřovský pripomína čitatelom, že dejiny ponúkajú množstvo príkladov úspešných, ušlachtilých homosexuálov ako napr. Michelangelo Buonarotti (1475-1564), Leonardo da Vinci (1452-1519), Svatopluk Čech (1846-1908), Hans Christian Andersen (1805-1875), Piotr Iljič Čajkovskij (1840-1893), Paul Verlaine (1844-1896) a d’alší. O nutnosti reformy § 129 I. b. trestního zákona. Vědecká práce pro 11. právnický sjezd v Brně 1925. Vypracoval JUDr. Frant. Čeřovský. Hlas sexuální menšiny 1, 15. 5. 1931, č. 2, s. 8 .

40 Oscar Wilde: Kněz a ministrant a nevydané dosud fragmenty z „De Profundis“. Hlas sexuální menšiny 1 , 30. 4. 1931, č. 1 , s. 6 .

41 Tamže.

42 Napr. Oscar Wilde. Hlas sexuální menšiny 1, 15. 7. 1931, č. 5-6, s. 5. V brnianskom Kamarádovi vyšla takisto báseň na počest̉ Oscara Wildea : Oskaru Wildeovi. Kamarád 1, 28. 5. 1932, č. 1, s. 6.

43 U hrobu Oscara Wildea (V srpnu t. r. na Pére La haise). Hlas sexuální menšiny 1, 15. 10. 1931, č. 12 , s. 12.

44 Prvá čast' úryvkov diela : Oscar Wilde: Kněz a ministrant a nevydané dosud fragmenty z „De Profundis“. Hlas sexuální menšiny 1, 30. 4. 1931, č. 1, s. 6.

45 Oscar Wilde: Obraz Doriana Graye. Hra o 9 obrazech. Dramaturgická úprava P. Vlka. Nový hlas 2, 1933, s. 141-143. 
vyzývalo príslušníkov sexuálnej minority k vzdávaniu úcty autorovi venovaním svojho času čítaniu Wildeových kníh. ${ }^{46}$

V tieni Oscara Wildea sa objavili tiež mnohé d’alšie osobnosti umenia svetového, ale aj domáceho československého formátu. Ich súhrnný počet je výrazne vyšší, než v prípade dvoch predošlých kategórií pripomínaných osobností. Z toho dôvodu vyberám pre ilustráciu iba niektoré z nich. Asi najstaršou spomenutou oslavovanou umelkyňou bola starogrécka lyrická poetka Sapfo (627-568 pr. n. 1.), ${ }^{47}$ ktorej špecifické miesto z hladiska historického veku dopíňa dôležitost̉ zastúpenia ženského pohlavia a lesbickej lásky. Tým bol v tlači vymedzený menší priestor. ${ }^{48}$

$\mathrm{Z}$ renesančného obdobia je žiaduce zmienit talianskych sochárov, maliarov a architektov Leonarda da Vinciho (1452-1519) ${ }^{49}$ a Michelangela Buonarottiho (1457-1564) či anglického básnika, dramatika a herca Williama Shakespearea (1564-1616). ${ }^{51}$

Väčšina pripomínaných umeleckých osobností však žila a pôsobila v 18. a 19. storočí. Tlač nezabudla na talianskeho huslistu a hudobného skladatel'a Niccola Paganiniho (1782-1840), ${ }^{52}$ nemeckého básnika a prekladatela Stefana Georgeho (1868-1933), ${ }^{53}$ na dánskeho maliara Einara Wegenera, neskôr po zmene pohlavia (tranzícii) Lili Ilse Elvenes (1882-1931) ${ }^{54}$ či ruského skladatel’a Piotra Iljjiča Čajkovského (1840-1893). ${ }^{55}$ Pri príležitosti 40. výročia úmrtia posledného menovaného napísal pražský Hlas článok, v ktorom s celkom unikátnym kritickým tónom apeloval na československú homosexuálnu komunitu: „Bylo by velmi potešujici, kdyby na večerech, vzpominajicích homoeroticky založených lidi, se objevili také jejich homosexuelni následovníci, jednak z piety, jednak, aby

46 K 15. ř́̆jnu 1931. Nesmrtelné památce Oscara Wildea. Hlas sexuální menšiny 1, 15. 10. 1931, č. 12, s. 10.

47 „S jejim jménem a jménem ostrova, jejž obývala, spojen je provždy pojem lásky ženy $k$ ženě [...] A jedné věci nelze se dosti obdivovati: cudnosti a čistotě $i$ těch nejvášnivějších projevũ básniřčiných, jež má dozajista svĩj pramen ve veliké duševni ušlechtilosti. "Lesbická láska. Hlas sexuální menšiny 1, 30. 4. 1931, č. 1, s. 4. Ženský element z umeleckej sféry zastupuje v predmetnej tlači okrem poetky Sapfo aj francúzska herečka Marie Raucourt (1756-1815) a francúzska maliarka Marie-Rosalie Bonheur (1822-1899), avšak iba krátkou zmienkou.

48 Dôvodom vymedzenia menšieho priestoru pre lesbické ženy mohol byt súhrn viacerých okolností. Hlavnou príčinou bol zrejme fakt, že na samotnej tlači československej sexuálnej menšiny participovali v prevažnej väčšine mužské homosexuálne osobnosti. Nižšie zastúpenie angažujúcich sa lesbických žien vo vydávaní časopisov mohlo byt zase výsledkom všeobecného podradeného genderového statusu žien. Takisto je nutné v tejto súvislosti podotknút, že historiografia 1. pol. 20. storočia sa výrazne orientovala na „dejiny bieleho muža“, čo je viditelné, i ked’ nie výlučne, aj v skladbe historických článkov predmetnej tlače.

49 Napr. Veliké uměni ženštivé. Přetištěno z 10. čísla revue „Gentleman“. Hlas sexuální menšiny 1, 15. 7. 1931, č. 5-6, s. 8 .

50 Napr. Rollandi̊v Michel Angelo. Nový hlas 2, 1933, s. 39-41.

51 Pražský Hlas publikoval niekol'ko Shakespearových sonetov (napr. XXVIII.) pričom popis k nim a autorovi pridal v článku: Několik slov o Shakespearových sonetech. Hlas sexuální menšiny 1, 2. 9. 1931, č. 9, s. 3-4.

52 Úryvek z novely Paganini. Jiři Karásek ze Lvovic. Předneseno na umělecké akademii v „Batexu“ 6. března 1932. Hlas. List sexuální menšiny 2, 15. 3. 1932, č. 6, s. 85-87.

53 Stefan George. Nový hlas 3, 1934, s. 1-3.

54 Různé. Druhé úmrtí Einara Wegenera. Hlas. List sexuální menšiny 2, 15. 3. 1932, č. 6, s. 94.

55 Petr Iljič Čajkowský. Nový hlas 2, 1933, s. 153-155. 
vzpomenuli, že i homosexuelni mohou učiniti vice pro lidstvo, nežli lítat po ulicích, anebo vysedávat denněv určitých lokálech za pochybnými účely. "56

$\mathrm{Z}$ československého umeleckého prostredia sa vyskytli iba tri holé zmienky mien. Spomenutí boli českí básnici a spisovatelia Josef Barák (1833-1883), Julius Zeyer (1841-1901) a Svatopluk Čech (1846-1908). ${ }^{57}$ Jasný dôvod, prečo sa v predmetnej tlači nevyskytla ani jediná slovenská osobnost’ a len žalostne málo českých osobností, nepoznáme. Časopisy sa pri výbere zdôrazňovaných historických individualít inšpirovali takmer výhradne zahraničným prostredím. Jednou z príčin tohto fenoménu mohla byt skutočnost', že bolo diskurzívne jednoduchšie pojednávat’ o sexualite istej zahraničnej, nie domácej osobnosti, a to pre rôzne konzekvencie. ${ }^{58}$ Ďalšou možnostou bola absencia historických výskumov či dôkazov o miestnych osobnostiach, ktoré by dokladali neheterosexuálne sklony. Do úvahy tiež pripadá eventualita snáh o vyzdvihnutie internacionálneho rozmeru homosexuálneho elementu, pri ktorom nezohrával žiadnu dôležitú úlohu československý nacionalizmus.

\subsubsection{Osobnosti politickej moci}

Typy pripomínaných osobností uzatvára skupina tých, ktorí vynikali svojím politickým vplyvom či postavením a zároveň vykazovali znaky neheterosexuálnej inakosti. Vybrané individuality politickej moci a popis ich vel'kého prínosu pre majoritnú spoločnost̉ slúžili ako dôkaz toho, že homosexualita nie je žiadnou domnelou slabostou či vylučujúcim symptómom, ktorý zabraňuje participácii človeka na vládnutí a riadení ludského spoločenstva. Pri týchto osobnostiach bol zdôrazňovaný silný, pevný charakter, múdrost', kvalifikovanost̉ či humanizmus. U mocných žien sa zase často špecificky vyzdvihovala emancipácia, usilovnost', produktívnost', bojovnost’ a odolnost'.

Zo širokého spektra osobností so značným politickým vplyvom možno vyzdvihnút napr. uhorského ministra Ferenca Deáka (1803-1876), ktorého pražská tlač podozrievala zo skrytého homosexuálneho založenia. Autor článku o Deákovi síce nemal v rukách jasné priame dôkazy o politikovej homosexualite, no napriek tomu využil vlastné domnienky k agitačným ciel’om československého hnutia sexuálnej menšiny. Niekdajšieho poslanca uhorského snemu však hnutie pochopitel’ne nechcelo zdiskreditovat', ba práve naopak: „Mnohi, najmä na Slovensku, kde Deáka dobre znajú, nám budú vytýkat', že odhalujeme jeho ,haňbu: Uistujeme preto každého, že homosexualita nie je žiadnou haňbou. "59 Deák bol v článku Hlasu označený za politického génia, kvalifikovaného uhorského diplomata, bojovníka za práva národnostných menšín, výborného rečníka, modernistu, re-

56 K 40. výroči úmrti Čajkovského. Nový hlas 2, 1933, s. 168.

57 Zmienka v článku O nutnosti reformy \& 129 I. b. trestního zákona. Vědecká práce pro 11. právnický sjezd v Brně 1925. Vypracoval JUDr. Frant. Čeřovský. Hlas sexuální menšiny 1, 15. 5. 1931, č. 2, s. 8.

58 Možné obviňovanie z ohovárania, právne dohry, konflikty, kontraproduktívnost’ - ublíženie oslavovaným osobnostiam a ich trestnoprávne a sociálne ohrozenie (pri stále živých), vyvolávanie silných kontroverzií a pod.

59 Minister Dr. František Deák. 1803-1876. Píše Imrich Matyáš z Bratislavy. Hlas sexuální menšiny 1, 15. 6. 1931, č. 4 , s. 6 . 
formátora či humanistu. Autor článku potreboval odôvodnit uverejnenie pre mnohých zrejme šokujúcej informácie nasledovne: „aby sme dokázali svetu, že homosexuálne osoby nie sú hordy zurhlých osob, ani žiadne párie l’udskej spoločnosti - ba opačne sú to tí, ktorí l’udu, národu a svetu svojou cennou prácou na poli kultúry a humanity mnoho cenného, ba nezbytného dobrého preukázali. “60

Pomerne rozsiahly článok bol venovaný aj bavorskému arcivojvodovi L'udovítovi Viktorovi Habsbursko-Lotrinskému (1842-1919), najmladšiemu bratovi cisára Františka Jozefa I. (1830-1916). U L'udovíta Viktora bolo prízvukované láskavé správanie a demokratické zmýšlanie. Autor článku ho označil za „najbystrejší rozum svojho rodu“, „mecenáša umenia“ či „homosexuálneho martýra“: „bol jedným z najuäčšich martýrov homosexuálných, ktorý vzdor svojho láskavého chovania a pre svoje demokratické smýšlanie, nemohol si získat' oblubu u viedeňskej kamarily a to len preto, lebo bol homosexuálným. "61 Rakúskeho šlachtica tlač velebila najmä za neskrývanie homosexuality pred verejnostou, ${ }^{62}$ za svoju šlachetnost' a dobročinnost. ${ }^{3}$ Okrem toho sa poukázalo na priamu toleranciu L'udovítovej homosexuality aj zo strany jedného z najvplyvnejších európskych mužov 19. storočia, Otta von Bismarcka (1815-1898). ${ }^{64}$

Za samostatnú triedu spomínaných mocných mužských autorít možno označit najvyšších cirkevných predstavitelov, rímskych katolíckych biskupov. Analyzovaná tlač ponúkla tri obsiahlejšie články o homosexuálnych pápežoch Levovi IX. (1002-1054), ${ }^{65}$ Júliusovi II. (1443-1513), ${ }^{66}$ Levovi X. (1475-1521) ${ }^{67}$ a bez širšieho popisu vymenovala aj niekolkých d’alších. Deklarovaným úmyslom publikovaných textov o hlavách rímskokatolíckej cirkvi bolo: „dokázat, že práve z najuynikavejšich synov katolicizmu boli mnohi homosexuální, ktori nijak neškodili svojej cirkvi, ale opačne jej na osoh a prospech. Žial' naproti tomu konstatujeme, že práve kresṫanské náboženské obce, najmä však katolická cirkev, spoločnost’ hlásajúca „lásku, uznanie a večný mier", vypovedaly nad homosexuálnými ortel zatratenia. "68

60 Tamže.

61 Ludevit Viktor. Píše Imrich Matyáš z Bratislavy. Nový hlas. List pro sexuální reformu 1, 1. 6. 1932, č. 2, s. 13. Totožný článok publikoval aj časopis Kamarád: Jeden homosexuelný mučedník. Píse Imrich Matyáš z Bratislavy. Kamarád 1, 28. 5. 1932, č. 1, s. 7-10.

62 „On, ktorý bol nad mierou obdarený pozemským bohatstvom a telesnou krásou, si zo svojho homosexuálného založenia vel'ké výčitky svedomia nerobil (a správne!). "Tamže.

63 „Jeho okúzlovacie chovanie, jeho vysoká morálka a v tichosti prevádzaná dobročinnost', prevýšovaly ostatných Habsburgov, ktori nesmierne bažili po telesných rozkošiach a nemraunostiach. " Tamže, s. 14.

64 „Bismark (1815-1898) nemecký kanclér, ktorý bol ochráncom a osobným priatelom bavorského homosexuálného krála Ludevíta II. (1845-1886) sa k arcikniežatovi stran jeho pohlavného založenia shovievave a zdržanlivo choval. "Tamže, s. 13.

65 Kristov zástupca pápež Leo IX. rozhodnul o homosexualite. Píše Imrich Matyáš z Bratislavy. Hlas sexuální menšiny 1, 15. 10. 1931, č. 12, s. 3-4.

66 Pápež Július II. 1503-1515. Nový hlas. List pro sexuální reformu 1, 1. 10. 1932, č. 6, s. 3-5.

67 Pápež Lev X. Nový hlas 2, 1933, s. 88-90.

68 Pápež Július II. 1503-1515. Nový hlas. List pro sexuální reformu 1, 1. 10. 1932, č. 6, s. 3. 
Medzi d’alšími pripomínanými vplyvnými mužskými osobnostami vynikli napr. pruský diplomat a dôverník nemeckého cisára gróf Philipp zu Eulenburg (1847-1921), ${ }^{69}$ pruský král' Fridrich II. Vel'ký (1712-1786) ${ }^{70}$ či francúzska transrodová osoba, diplomat Chevalier d'Éon (1728-1810). ${ }^{71}$

Jediný súvislý text o homosexuálnej osobnosti ženského pohlavia tejto kategórie bol venovaný švédskej královnej Kristine I. (1626-1689), ktorá „cestovala po svém zřeknutí se švédského trůnu pod jménem, hrabě Dohny“. Potloukala se v lesich, nocovala pod širým nebem nebo v některém dvorci a zdivočela. "72 Krátkymi zmienkami sa ešte pripomenula napr. dánska královná Karolina Matylda Hannoverská (1751-1775), francúzska vojačka Jana z Arku (1412-1431) či ruská okultistka a filozofka Helena Petrovna Blavatská (1831-1891).

\subsection{Pripomínané kultúry}

Druhú základnú formu, prostredníctvom ktorej tlač československej sexuálnej menšiny inštrumentalizuje queer dejiny, predstavujú spoločenské kultúry v rozličných geografických prostrediach. Figúrami spomínania ${ }^{73}$ sú tak minulé, v niektorých prípadoch aj stále aktuálne - prítomné kultúry, ktoré sa stávajú vzormi a príkladmi toho, ako by československá spoločnost̉ mala či nemala vyzerat'. V článkoch s týmto charakterom sa tak stretávame s odkazmi, ktoré načrtávajú dva základné vzory popisovaných kultúr, pozitívne a negatívne.

\subsubsection{Pozitívne vzory kultúr}

Spoločenské kultúry, v ktorých sa homosexualita či homosexuálna láska vyskytovali ako „prirodzená, normálna a bežná súčasť života“, sa automaticky stávajú elementárnym zdrojom pripomínania pozitívnych vzorov. Prostredníctvom historických exkurzov do týchto kultúr autori článkov prevažne silno idealizujú ich spoločenské pomery vzhladom k homosexualite. Tá je tu prítomná bez systematicky riadenej perzekúcie, je prijímaná pozitívne, je prirodzenou súčastou kultúry, v ktorej sa vyskytuje. Kultúry tak často slúžia ako príklad ideálov, hodnôt či morálky, alebo takisto ako funkčný príklad bezproblémového spolunažívania sexuálnej menšiny s väčšinovým obyvatel’stvom.

69 Hlas v tomto prípade kritizuje politicky motivované, nel’udské a nelogické trestné stíhanie grófa Eulenburga pre jeho homosexuálne styky. Vyčíta tiež médiám, že z podobných prípadov vytvárajú vel'kú senzáciu, vd’aka ktorej účel svätí prostriedok. Eulenburg. Otiskujeme článek z Národního obzoru z 18. VII. 1908 pro zajimavost názori̊ v tehdejši době. Nový hlas 1, 1933, s. 28-30.

70 Virilismus slavných mužư. Nový hlas 3, 1934, s. 65.

71 Muž nebo žena? Hlas sexuální menšiny 1, 1. 6. 1931, č. 3, s. 12. alebo aj Chevalier d'Eon, člověk záhada. Nový hlas 1, 1933, s. 177 .

72 Švédská králowna Kristina. Tamže, s. 176.

73 Figúry spomínania sú jednotlivé ucelené časti minulosti (udalosti, osobnosti, ale tiež normy a hodnoty), ktoré získali charakter pojmu, symbolu, náuky. Sú vzormi, príkladmi či akýmisi poučkami. Neprodukujú iba minulost' určitej skupiny, ale definujú rovnako jej esenciu, vlastnosti a slabiny. Assmann, Jan: Kultura a pamět. Písmo, vzpomínka a politická identita v rozvinutých kulturách starověku. Praha 2001, s. 40. 
Najčastejšie pripomínanou velmi výrazne zidealizovanou historickou epochou bola antika, najmä kultúra starovekého Grécka: „Staré Grécko tak učinilo, povolilo ba podporovalo homosexuálnu lásku a tým využitkovalo a t’ažilo vel'ké kultúrné a majetkové dobro pre štát a človečenstvo. Kdo zná dôkladne grécku historiu, $k$ povedanému prikývne a kdo sledoval vývin europskej kultúry najde, že vo starej antickej kultúre má lvi podiel homosexuálna láska a na tejto homosexuálnej gréckej kultúre je budovaná dnešná kultúra, ovšem brzdená krestanstvom. "74 Pre doloženie „normálnosti či prirodzenosti“ homosexuálnych prejavov v starogréckej spoločnosti uvádza predmetná tlač mnohé príklady z gréckych bájí a mýtov, ${ }^{75}$ poukazuje na obrovský počet homoerotických prejavov v sochárstve a literatúre ${ }^{76}$ či na vojenskú tradíciu starovekej Sparty, v ktorej bola „povinnost' každého muža milovat’ iného muža “.77

Súčastou pozitívneho naratívu o ideáloch a hodnotách antiky je tiež niekol'ko desiatok básní a prozaických príbehov, ktoré čerpajú inšpiráciu práve z tohto historického obdobia a romantizujú homosexuálnu prítažlivost'. Model čistej lásky medzi rovnakým pohlavím reprezentuje napr. príbeh o Alexandrovi Vel'kom ${ }^{78}$ alebo báseň o spomínanej starogréckej lyrickej poetke Sapfo. ${ }^{79}$ Tlač nezabúda pripomenút ani významné osobnosti gréckej a rímskej filozofie, ktoré homosexuálnej láske medzi mužmi pripisovali pozitívne konotácie. Príkladom je Sokrates píšuci o vysokom mravnom cieli Helénov ${ }^{80}$ či Platón pojednávajúci o dvojakej láske, Erose pozemskom a nebeskom. ${ }^{81}$ Prostredníctvom osoby rečníka, štátnika a filozofa Cicera a tiež cisára Caligulu sa napokon dostávame aj do prostredia antického Ríma. Obaja menovaní sa v tlači vyskytli pre svoj ideál priatel’stva a lásky medzi mužmi. ${ }^{82}$

Autori článkov tlačovín československej sexuálnej menšiny sa obzreli aj po starších dejinách. Zaujímavá bola pre nich takisto praveká kultúra, v ktorej ešte neexistovali manželstvá, ani iné pevne zviazané l’udské zväzky medzi jednou ženou a jedným mužom. Pri pravekej spoločnosti sa predpokladalo, že sexuálna aktivita bola výraznejšia, sexuálne styky boli neviazané, najmä zmyselné s ciel’om fyzického uspokojenia človeka, pričom

74 Ludevit Viktor. Píše Imrich Matyáš z Bratislavy. Nový hlas. List pro sexuální reformu 1, 1. 6. 1932, č. 2, s. 12-13.

75 Spomínaná je napr. grécka báj o Diovi, ktorý si oblúbil mladého Ganymeda, o bohovi Apollonovi a jeho „miláčikovi“ mladíkovi Hiakynthovi či o hrdinovi Achillovi a jeho priatel’ovi Patroklovi. Řecká láska. Hlas sexuální menšiny 1, 15. 5. 1931, č. 2, s. 8-9.

76 O takú tvorbu sa postarali vymenovaní grécki básnici Alkaios, Pindaros a Anakreón, sochári Myrón, Lysippos, Feidias, Skopas či Polykleitos. Tamže, s. 9.

77 Co každý neví. Hlas. List sexuální menšiny 2, 1. 3. 1932, č. 5, s. 79.

78 Kofa. Věnováno p. Jos. Hladkému. Nový hlas 2, 1933, s. 52-54.

79 Antická kamej : Sapfo se louči s prítelkyni odcházející do Babylonie navždy. Nový hlas. List pro sexuální reformu 1, 1. 5. 1932, č. 1, s. 2.

80 Řecká láska a my. Hlas sexuální menšiny 1, 15. 6. 1931, č. 4, s. 10-11.

81 O dvoji lásce. Nový hlas 2, 1933, s. 137.

82 Slová rímskeho štátnika Cicera o pojatí priatel’stva medzi mužmi použil v príhovore Jiří Karásek ze Lvovic na valnom zhromaždení osvetového a spoločenského združenia „Přátelstvi“ 6. marca 1932. Prepis príhovoru publikoval časopis Hlas: Ǩě Mistra Jiřiho Karáska ze Lvovic na valné hromadě sdruženi „Přátelstvi“. Hlas. List sexuální menšiny 2, 1. 4. 1932, č. 7, s. 103. Prozaický príbeh o rímskom cisárovi Caligulovi, ktorý prosí boha Jupitera o lásku k mužom po vzore Dia a Ganymeda, bol uverejnený takisto v Hlase: Smrt Caligulova. Nový hlas 2, 1933, s. 41-43. 
bola prítomná aj homoerotika. Tým dávali najavo: „Názor, že t.zv. ,perversity“ jsou choroby kulturni a jevy degenerační, neni nijak prokázán, nebot’ se vyskytuji u národů primitivních a naprosto zdravých. "83

Americký kontinent ponúkol pozitívne vzory pripomínaných kultúr u „amerických Grékov“ - Indiánov. Skúmané a popisované znaky kultúry praobyvatel’stva Ameriky totiž nabúrali stereotypnost’ pohladov na binárne genderové rozloženie a fungovanie európskej spoločnosti. Indiánska kultúra vykazovala pevné intímne väzby medzi príslušníkmi mužského pohlavia, naznačovala harmonickú symbiózu l’udského života s prírodou, pri ktorej boli homoerotické prejavy jej bežnou súčastou. ${ }^{84}$

V historickom exkurze do ázijského prostredia sa tlač pozrela na čínsku, japonskú, indickú, mongolskú a orientálnu kultúru. Poukázalo sa na pederastiu v čínskej spoločnosti, ktorej korene siahajú až do obdobia vládnutia dynastie Chan približne 200 rokov pred n. 1., na tradičnú pederastiu medzi mongolskými mníchmi, ${ }^{85}$ na nespútaný sexuálny život a homosexuálnu lásku orientu, ${ }^{86}$ na často zastúpený homosexuálny prvok a tiež hermafroditizmus v indickom hinduizme ${ }^{87}$ či na niekol'ko homoerotických vyobrazení v japonskej literatúre ${ }^{88} \mathrm{Na}$ africkom svetadiele boli nájdené pozitívne vzory v kultúre kmeňa Tuaregov, ktorých poézia zaznamenala známky homoerotizmu u afrických mužov. ${ }^{89}$

Úplne posledným vytypovaným kultúrnym vzorom pripomínania boli zmienky o štátoch, v ktorých už homosexualita údajne nebola trestnoprávne postihovaná. Tieto krajiny boli označované aj ako „kultúrne štáty“: napr. Francúzsko, Belgicko, Portugalsko, Švajčiarsko, Srbsko, Taliansko, Nemecko, Japonsko, Čína, Turecko či Rusko. ${ }^{90}$

\subsubsection{Negatívne vzory kultúr}

Československé hnutie sexuálnej menšiny pripomína niekol'kokrát prostredníctvom tlače aj negatívne vzory. Absolútne dominuje kritika stredovekej krestanskej morálky a krestanskej katolíckej cirkvi, v ktorých členovia hnutia videli vel'kých nepriatelov homosexu-

83 Pud pohlavní a láska pračlověka. Hlas. List sexuální menšiny 2, 13. 2. 1932, č. 4, s. 53.

84 „Právě zde u těchto mravně vysoko stojicich lidi setkáváme se s oním pojetím lásky, o jakém dosud slyšeli jsme jen ze starého Řecka, prátelstvím mezi muži a chlapci a muži s muži, jež vyznívá v nejnádhernějši symfonii dvou milujicích se duši, jež strhuje svou vroucnosti, vznešenosti, ideálnosti. “ Ze života Indiánů. Nový hlas. List pro sexuální reformu 1, 1. 9. 1932, č. 5, s. 4 .

85 O tradičnej čínskej a mongolskej pederastii informuje článok: Pederastie v Č́ně. Nový hlas 2, 1933, s. 107108.

86 „Orient se suým bouřlivým projevem sexu je spravedlivější, než vzdělanecky omezená střední Evropa. Orient poskytuje rovnocennost stejnopohlavni lásky. "Homosexualita, resp. pederastia bola považovaná za bežnú, nezávadnú vec údajne na Balkáne v Záhrebe, Sarajeve, v tureckom Trabzone, v tureckej provincii Samsun či v libanonskom Bejrúte. Orient a homosexualita. Nový hlas 3, 1934, s. 50-51.

87 Zdôraznený bol hermafroditizmus najvyššieho hinduistického božstva Brahma. Co každý nevi. Hlas. List sexuální menšiny 2, 1. 3. 1932, č. 5, s. 79.

88 Publikovaných bolo niekol'ko vybraných historických japonských básní (z 10. až 18. storočia) s obsiahnutou homoerotikou. Japonské pisně lásky. Nový hlas 2, 1933, s. 49-50.

89 Odjezd k Ahâl. Z poesie kmene Tuaregů. Tamže, s. 100.

90 Aby bolo jasno! Kamarád 1, 28. 5. 1932, č. 1, s. 1. 
álov. Oba subjekty predstavovali pôvod silného spoločenského a právneho útlaku homosexuality v Európe. Autori článkov sa na rôznych miestach ohliadajú do minulosti, aby kritizovali to, čo podla nich zapríčinila stredoveká krestanská morálka: „zaveden byl vlivem křestanství ve většině států křestanských na homosexualitu trest smrti a to po dobu celého středověku. [...] Na tisice lidi padlo za obět tomuto justičnímu omylu a nikdy nebude znám přesný počet těchto neštastniků. "91

V súvislosti s kriminalizáciou homosexuality ako výsledkom krestanskej snahy o rekonštrukciu spoločnosti popisujú absurdity stredovekého súdnictva ${ }^{92}$ a kritizujú domnienku, že krestansky motivované stredoveké súdnictvo a morálku zdedilo mnoho moderných európskych štátov nevynímajúc Československú republiku. Homosexuálov v kontexte právnej a spoločenskej perzekúcie často označujú za „najväčších martýrov dejín, trpitelov, obete spoločenských predsudkov“ a pod.: „ani jeden národ nemal a nemá tol'ko nevinných obeti a mučednikov, jako je obec homosexuálná. “93

\section{Záver}

Pripomínanie queer minulosti v medzivojnovej periodickej československej tlači sexuálnej menšiny plnilo niekol'ko základných účelov. Poukazovalo sa na kontinuálnost̉ existencie homosexuality vo všetkých dejinných etapách l’udstva a v rôznorodých geografických prostrediach. Prítomná bola snaha o zdôrazňovanie toho, že fenomén homosexuálnej lásky je v celosvetovej spoločnosti ukotvený odjakživa. Tým spôsobom sa československé hnutie sexuálnej menšiny usilovalo o legitimáciu inakosti, ktorú výsostne reprezentovalo. Sexuálnu menšinu inštalovalo do celkovej ludskej society ako jej d’alšiu špecifickú sociálnu skupinu. Okrem toho bolo eminentným záujmom predmetnej tlače dokazovat prirodzenost’ či normálnost’ homosexuálneho človeka. Mnohé príspevky preto približovali útrapy, bolesti, krivdy ale aj výnimočnosti či značné spoločenské úspechy rozličných známych neheterosexuálnych ludí naprieč svetovými a československými dejinami. Vyzdvihovaná bola ich užitočnost', ušlachtilost’, pričinenie o blaho väčšinovej spoločnosti, a zároveň akcentovaná vysoká miera spoločenskej nespravodlivosti voči nim, ktorú hnutie žiadalo napravit'. Minulost’ tak poslúžila ako vhodný odrazový mostík na ceste k búraniu spoločenských predsudkov, k apelu na dodržiavanie l'udských práv a budovaniu rovnosti.

Dôležitým momentom pri analýze tlače bolo zistenie, že v nej chýbajú pravidelne pripomínané akési najvýraznejšie, najvýznamnejšie špecifické medzníky, mílniky či sviatky, pričom práve tie sa vo všeobecnosti často stávajú hlavnými bodmi kreovania kolektívnej pamäte u mnohých ludských spoločností. Jedinými náznakmi tohto charakteru boli opakované články o životných osudoch a osobných výročiach írskeho básnika a dramatika Oscara Wildea (1854-1900) a nemeckého sexuológa a homosexuálneho aktivistu Magnusa Hirschfelda (1868-1935). Z môjho pohladu túto absenciu zapríčiňuje fakt, že

91 O nutnosti reformy § 129 I. b. trestního zákona. Hlas sexuální menšiny 1, 1. 6. 1931, č. 3, s. 4.

92 Predstava, že netrestanie homosexuality spôsobuje mor, hlad, potopy, zemetrasenia, premnoženie polných hrabošov a myší. Tamže.

93 Jeden homosexuelný mučednik. Kamarád 1, 28. 5. 1932, č. 1, s. 7. 
prvorepubliková realita umožnila vznik úplne prvého československého hnutia sexuálnej menšiny, a teda aktivizovanie sa pár desiatok osobností, ktoré iba rozprúdili agitačný boj za zrovnoprávnenie neheterosexuálnych občanov prostredníctvom rôznych platforiem, pričom jednou z nich bola tlač. Tvorba akejsi hlbšej kolektívnej pamäte sexuálnej menšiny v československom geografickom priestore iba započala. Je preto celkom dôvodná myšlienka, že vznik „najväčších“ mílnikov, medzníkov či sviatkov ešte len čakal na svoje kreovanie. Ostatne je celkom na mieste otázka - čo iné okrem významných osobností či zidealizovaných dejinných kultúr si mohla československá neheterosexuálna komunita pripomínat, ked’ sa jej boj na verejnom politickom poli iba rozpútal? Čo si vlastne mohla pripomínat, ked' v sledovanom období iba „bojovala o prežitie“, o „vlastné miesto pod slnkom"?

Každopádne, queer dejiny nepochybne našli svoj priestor v tlači československej sexuálnej menšiny, ked’že články s historickými exkurzmi sa tu vyskytujú takmer v každom jednom čísle niekol'kokrát. Tento fenomén iba potvrdzuje, že dejiny sú dôležitým prvkom pri budovaní akéhokolvek ludského spoločenstva. Figúry spomínania v tlači sa evidentne mali stat’ vzormi, príkladmi či akýmisi poučkami života československej sexuálnej menšiny. Formulovaný bol skrze ne všeobecný postoj hnutia, dúfajúc a nabádajúc v rovnaký postoj každého príslušníka československej neheterosexuálnej komunity. Špecifikom spomínaných queer dejín sa stala ich vysoká miera internacionálnosti paradoxne v období bujnejúceho európskeho nacionalizmu.

\section{Queer past commemorated in press of the sexual minority during the first Czechoslovak Republic}

Commemorating the queer past in the interwar Czechoslovak press of the sexual minority had several basic purposes. The continuity of homosexuality in all historical periods and in diverse geographical environments was pointed out. Attempts to emphasize that the phenomenon of homosexual love has been a part of global society have been made. This was the way the Czechoslovak Movement of the Sexual Minority strived for the legitimization of the otherness that it represented. It installed the sexual minority in the human society as another specific social group. In addition, there was a vested interest of the press in question to prove the nature or normality of a homosexual person. Many articles have therefore described hardships, pains, injustices but also the uniqueness and considerable social achievements of various well-known non-heterosexual people across both the world and Czechoslovak history. Their usefulness, nobility, the cause of their contribution to the whole society, and the accentuated high level of social injustice towards them were highlighted and the movement sought the remedy of the latter. Thus, history has served as a useful tool for demolishing social prejudices, appealing to human rights and building equality. An important discovery of this analysis of the press was the fact that it lacks of some of the most distinctive, most significant specific milestones or memorial days, which would be regularly commemorated. These are often the main points, which serve for creating a collective memory in many human societies. The reason is that the creation of collective memory only began after the establishment of the Czechoslovak Movement of the sexual minority during the period of the First 
Czechoslovak republic. Anyway, queer history has undoubtedly found its place in the press of the Czechoslovak sexual minority as articles with historical excursions appear in almost every single issue several times. This only proves that history is an important element in building any human community. The figures of the commemorating in the press were clearly to become role models, examples or a kind of lessons of the life of the Czechoslovak sexual minority. A general attitude of the movement was formulated through them, hoping and encouraging the same attitude of every member of the non-heterosexual community. Paradoxically, in the period of booming European nationalism, the high degree of internationality has become a specific feature of queer history. 
